\title{
Schrodinger's Narratives:
}

\section{Denis Diderot's and Laurence Sterne's Manipulations of Time and Space}

\author{
Ziggy Ghassemi \\ zghassemi@g.ucla.edu
}

This article proposes connections between literature and science through the relatively recent scientific concept of chaos. I examine Laurence Sterne's The Life and Opinions of Tristram Shandy, Gentleman and Denis Diderot's Jacques the Fatalist and His Master to show how these authors contradict the scientific thinkers of their time by creating narrative structures that disrupt the normal flow of time and bend the typically absolute space between reader and fictional story. Though the physical books of Jacques and Tristram Shandy have a final page, the two authors leave it to their readers to finish the stories for themselves. The narrators of both novels interact with their readers, creating a space that allows their audience to fill in the narrator's and author's blanks. In doing this, these texts become simultaneously complete and incomplete. Thus, a narrative styled similarly to the thought experiment of Schrodinger's cat is created. In this sense these novels can be perceived as precursors to scientific thought of the twentieth and twenty-first century.

Keywords: Time, Space, Sterne, Diderot. 


\title{
Schrodinger's Narratives:
}

\section{Denis Diderot's and Laurence Sterne's Manipulations of Time and Space}

\author{
Ziggy Ghassemi \\ zghassemi@g.ucla.edu
}

«Tempus item per se non est, sed rebus ab ipsis consequitur sensus, transactum quid sit in aevo, tum quae res instet, quid porro deinde sequitur: nec per se quemquam tempus sentire fatendumst semotum ab rerum motu placidaque quiete»

«Time also exists not of itself, but from things themselves is derived the sense of what has been done in the past, then what thing is present with us, further what is to follow after.

Nor may we admit that anyone has a sense of time by itself separated from the movement of things and their quiet calm» ${ }^{1}$.

\section{Introduction}

Interaction with time and space has fascinated people from all over the world since the two concepts were first conceived. From scientists to philosophers, writers, and critics, how humanity perceives the space that it inhabits and how they move through it has been a topic of discussion since before antiquity. The passage above demonstrates this as Ancient Roman philosopher Lucretius shares his views in his work De Rerum Natura. In On the Nature of Things, time cannot be perceived in any way other than through the changes it wreaks on the physical world. Political philosopher John Locke described movement through time and space in a similar manner, as an association of ideas. This understanding is formed by reflecting on those ideas which occur within the mind. Locke called this progression from one thing to the next

\footnotetext{
${ }^{1}$ T. L. Carus, De Rerum Natura, translated by W.H.D Rouse and Martin Ferguson, Smith, Harvard University Press, Cambridge 1975, p. 39.
} 
«succession» ${ }^{2}$, and duration can only be perceived by reflecting on the distance between these ideas. On the other hand his contemporary, the great natural scientist Sir Isaac Newton, defined space as an absolute: where time and space are not reliant on any sort of physical event or experience, they are absolute constants. Both of these views create a symmetrical system in which time flows constantly from one event to the next and the way in which people move throughout this symmetrical space is similarly symmetrical.

Two mid-eighteenth-century authors, Laurence Sterne and Denis Diderot abolish both concept of the symmetric flow of time and space as they manipulate it in their respective works The Life and Opinions of Tristram Shandy, Gentleman and Jacques the Fatalist and his Master. Both authors offer up counter theories to the philosophies of time and space listed above. Both authors share a contempt for anything absolute - the space on their pages, a normally absolute space, is anything but absolute. Both narrators in both stories jump out of the page to address the reader. Thus, the page becomes a sort of three-dimensional object, an object that can be interacted with instead of the book being the static object it generally is.

Diderot and Sterne also similarly manipulate time in their novels. When a reader picks up a novel, they expect that the novel has a beginning, a middle and an end. They expect it to flow with symmetry from start to finish. Though readers expect outside interruptions, they do not expect the flow to be interrupted by the characters inside the book. In Sterne's novel, his narrator Tristram Shandy controls his audience and interacts with them in ways that make reading more of a social construct than a solo activity. Tristram will literally interrupt his own life story to tell his readers what to do next or how to read it. Comparably, Diderot's narrator interrupts the story of Jacques's love life with other people's stories, creating a metadiegetic narrative. However, this comes with the threat of not being able to finish the main plot. These interruptions disrupt the linear, symmetrical progression of the novel, throwing the readers off their guards. In the same way that Laurence Sterne manipulates time throughout his novel Tristram Shandy, Denis Diderot manipulates movement to create the illusion of progression through time in his novel Jacques the Fatalist. Though his methods are different than Sterne's, Diderot bends linearity in a similar manner, breaking the symmetrical quality of time. Both authors make passage through time

\footnotetext{
2 J. Locke, An Essay Concerning Human Understanding, Prometheus Books, Buffalo 1995, pp. 105-106.
} 
neither calm nor quiet nor constant. In a human ecosystem that was becoming ever more ruled by the idea of the absolute, these works hold in contempt the idea of an absolute concept of reality. Through narrative interruption, digression, the blending of authorial voice with the outside reader, Jacque's and Shandy's tales creates a new concept of time and space: one that is interactive.

\section{Diderot: Jacques the Fatalist and His Master}

Diderot's Jacques the Fatalist and His Master bends movement within the novel in a couple of distinct ways. If movement can be taken as linear progression through the text of the novel, i.e., physically flipping the pages, then there indeed is an end. However, the illusion of progression is created when the reader realizes that the main plot line of the story never actually ends as Jacques himself predicts «I have this awful feeling that my story will not get finished» ${ }^{3}$. Instead, through every digression and interruption within Diderot's novel, the main story stagnates seemingly somewhere in the middle of their journey. As George Saintsbury says of Jacques in his book A History of the French Novel (To The Close of the $19^{\text {th }}$ Century) «the very unedifying account of the loves, ... is deliberately, tediously, inartistically interrupted and "put off" $»^{4}$. This putting off of the story, leaves the reader in a sort of limbo between the start and the end, and indeed by the last physical page, «not best pleased» with how it turned out ${ }^{5}$. The novel undermines progression from its very first page to the last. Even though Jacques and his master do get to where they are going, they never finish the story of Jacques's love. The perfect symmetry of narrative plot is broken by constant interruption and digression. Movement itself is confined only to the physical space inside the story, through which Jacques and his master are constantly moving.

\footnotetext{
${ }^{5}$ Ibid, p. 312.

${ }^{4}$ G. Saintsbury, A History of the French Novel: To the Close of the 19th Century, Russell \& Russell, Inc., New York 1964, p. 405.

${ }^{5}$ D. Diderot, Jacques the Fatalist and His Master, tr. eng. by D. Coward, Oxford University Press, Oxford 1999, p. 312 .
} 
This movement within Jacques creates the illusion of progression through the plot as Jacques and his master are constantly moving to get to their ambiguous destination. Ordinarily characters moving in a novel would normally indicate that the story is moving with them, however, that is not the case in Jacques. It is commonly believed that Jacques starts in media res, as the reader is plopped right into the middle of a conversation. Because of the stress Diderot puts on starting the novel in the middle of a conversation, the illusion is created that the reader has indeed begun the story in media res. Roy Chandler Caldwell however says that, rather than in media res, «the story opens ... ante res», before things ${ }^{6}$. In starting this way, the reader is fed the possibility that they were thrown in before the story and that they will progress linearly, symmetrically with the characters through the text, just as Jacques and his master are physically progressing to their final destination, wherever that may be. The narrator supports the idea of ante res as he even declares that «you were here before you arrived, and you will be here after you are gone» ${ }^{7}$. This message to the reader also states however, that even after the readers are finished with the novel, they will never be finished with it. This furthers the illusion of progression since the reader is constantly a participant in the formation of its plot. Just like entering a conversation midway and leaving before it is finished, Jacques has no beginning (at least one made privy to the reader), no middle and no end and the participants of the conversation will constantly dwell on it after the fact, rethinking what each said and did millions of times. As Andre Blink in his book The Novel: Language and Narrative Form from Cervantes to Calvino states «Diderot ... constructs his whole novel on the principle of dialogue, but this interactive process ... presents language throughout as an activity cut loose from the moorings of the here-and-now» ${ }^{8}$. Diderot stresses this with the structure of the novel, as it is structured like a conversation, focusing on mainly dialogue. The structural form of a conversation inherently creates interaction between participants be it through direct address by the narrator, or indirect address by Jacques himself.

\footnotetext{
${ }^{6}$ R. C. Caldwell, Backtalk: Agonistic Dialogue in "Jacques Le Fataliste”, in "Diderot Studies”, XXVI, 1995 , pp. $29-45$. p.31

${ }^{7}$ D. Diderot, Jacques the Fatalist and His Master, cit. p. 65.

${ }^{8}$ A. Brink, The Novel: Language and Narrative from Cervantes to Calvino, New York University Press, New York 1998, pp. 86-87.
} 
Like Diderot, Sterne also created Tristram Shandy in a way that made reading a social act. Unlike Tristram Shandy however, the dialogue in Jacques, is in fact, the most important aspect of the novel. There is very little narrative, and even when the narrator speaks, it is in dialogic form. In this it differs from Tristram Shandy, where even though Tristram is speaking to his audience, there is more descriptive dialogue and narration. Diderot's Jacques is centered solely on dialogue, structured more like a play. However, it is not a play, and borrows aspects from both art forms (theatrical play and novel) and in doing so is once again able to subvert the expectations that come with picking up a traditional novel or a traditional play. This structure enables the narrator to interact with the audience in a more organic manner than in Shandy. Many times, throughout Jacques, the narrator threatens to stop the story of Jacques's loves because the reader is asking too many questions. The narrator, true to Sternian form, withholds information from the reader and tells readers to fill in the blanks for themselves. One spot where this is seen is at the end when the narrator says to the reader «If you are not satisfied with what I have revealed to you of Jacques's loves, Reader, why not try to do better yourself?» ${ }^{9}$. This specific interaction with the reader at the end of the novel suggests that even though the physical book has ended, the story is left open. It throws out any perception the reader had about Jacques being a single story, traversing one single plotline. It creates a chaotic, multiversal metadiegetic narrative, throwing out the idea of one absolute, sacred, plotline. Though not many readers would try to do better for themselves, the narrator leaves the option on the table, creating a text that is at once finished and unfinished, reminiscent of Shandy.

Diderot creates the illusion of movement with the dialogue of Jacques the Fatalist by actually having Jacques proceed - at intervals - with the story of his loves. However, every time Jacques gets to a significant spot in his story, there is an interruption or, digression of some sort caused by an outside force. Diderot manipulates the time it would take for Jacques to normally tell a story by stretching it out to the point where there are not enough pages in the book to finish it satisfactorily. Of course, the reader can skip these digressions and interruptions as they add nothing to the story of Jacques's loves, but few readers who pick up a book would do that. Even that would be shortening the length of time it would take to get to the end of the novel. Thus,

${ }^{9}$ D. Diderot, Jacques the Fatalist and His Master, cit., p. 343. 
within the tale, time as is not as absolute as Newton would have his followers believe. The two hour and thirty-three-minute audio book only accounts for the reader listening through in a conventional manner, listening to all of the dialogue. Like the time allotted to Tristram Shandy's audio book, the time allotted to Jacques is not absolute, but fully subjective to the listeners and readers whim.

In the same way that time is not absolute in Jacques, neither is space. In Jacques, space is the narrator's plaything. Where the space on the page is usually something held sacred, immovable, and absolute as Newton's theory would require, Jacques's narrator rips open the usually inaccessible space between physical novel and reader. In doing so, he gives the novel a threedimensional aspect as mentioned above. Though nothing physical ever moves on the page to rearrange the actual text, the characters of Diderot's novel, namely Jacques himself and the narrator, almost physically reach out and grab the readers' attention. This is done by the narrator interrupting the story with quips to the reader and telling the readers to rewrite the climax for themselves.

All standard forms of narrative are diegetic: the primary set of events is contained within the story. An act of narrative that is outside the story is extradiegetic. Finally, metadiegetic refers to interruptions, digressions, and other stories within the story. In Jacques, the narrator interrupts the main story several times, addressing the reader, speaking to the reader, and even commanding the reader. This creates a chaotic extradiegetic level as it warps the typically static space in between reader and narrator. It is bent to the point where it becomes a conversation instead of a narrative, another dialogue through which the reader must navigate. These interruptions, which are present in Diderot and Sterne's works highlight the dialogic nature of both Jacques and Shandy. They are perfect examples of Rene Wellek and Austin Warren's line «literature is a social institution» ${ }^{10}$. Diderot utilizes the space of the page in his novel in order to make the reader interact with his text, therefore making it a «tool of thought» rather than just an artifact of culture ${ }^{11}$. In becoming such, Diderot, like Sterne, introduces the element of chaos into the very act of reading, since it is the act of reading which gives the text its meaning. In reading a

\footnotetext{
${ }^{10}$ R. Wellek, A. Warren, Theory of Literature, Harcourt, Brace and World, New York 1956, p. 94.

${ }^{11}$ H. Lefebvre, The Production of Space, Blackwell, Hoboken1992, p. 26.
} 
normal, static narrative, the reader is presented with a sequential chain of events, and can easily pick from the absolute, an abstract meaning. However, in Jacques as in Tristram Shandy this is not the case. The two authors work to make their readers interact with their narrators - Tristram, the narrator in Jacques - and the authors themselves. This pushes reading from an individual experience, to a social one as the reader is no longer interacting with just the physical object, but also the author and voices of the texts.

By making reading a social act frees the participants to quit the conversation whenever they so please. The narrator in Jacques threatens to do so on multiple occasions. In the very beginning of the text, the alleged reader is called out for asking too many logistical questions and frustrates the narrator, who indeed threatens to not even tell the story of Jacques' loves, «"where were they on their way to? That's the second time you've asked that question, and here's the second time I answer: What's it to you? If I get launched on the subject of their travels, you can kiss the story of Jacques's love affairs goodbye" ${ }^{12}$. This interaction with the narrator alone transforms the fictive narrator into an actual person telling a story, becoming frustrated by being interrupted, building on the social aspect of reading. This form of address bends the typically solid wall between the narrator and reader, obfuscating the boundaries between story and reality. Diderot uses the conversational tone of the novel to create a narrative of metalepsis, defined by French literary theorist Gerard Genette to mean «any intrusion by the extradiegetic narrator or the narratee into the diegetic universe $\ldots$ or the inverse» ${ }^{13}$. This kind of narration demolishes the concept of a symmetrical space between reader and story as it breaks down the wall between reality and fiction: what is known as the fourth wall.

At the end of the story, Sterne's influence on Diderot becomes blatant when the narrator addresses the reader. Through all of the interruptions, digressions, and other breaks in the story, Jacques was not able to finish the story of his loves as he feared in the beginning. While on the surface layer, this emphasizes that the world is run by fate; fatalism is actually cast away. The narrator does this in the loudest and most Sternian form of metalepsis possible, by leaping outside of the physical page declaring «Look, Jacques said over and over that it was written on

\footnotetext{
${ }^{12}$ D. Diderot, Jacques the Fatalist and His Master, cit., p. 83.

${ }^{13}$ G. Genette, Narrative Discourse: An Essay in Method, Cornell Univ. Press, Ithaca, NY, 2000, pp. 234-235.
} 
high that he'd never finish the tale, and I now see that he was right. I can tell, Reader, that you are not best pleased. Well, why don't you pick up his story at the point where he left it yourself, and continue it as you think best?» ${ }^{14}$. By suggesting the reader do such a thing, Diderot brings in an element of metaleptic chaos not yet seen in Jacques. While the interruptions and digressions warped the flow of time in the novel, time was already warped in Jacques to begin with. Though the readers themselves are able to bend linear movement through the novel by skipping the digressions that have nothing to do the tale of Jacques's love, this form of chaos still has an element of manipulation to it. However, by pitching to the reader to write the ending themselves opens up Jacques to millions upon millions of alternate endings, creating true chaos as it leaves Jacques, like Shandy, both finished and unfinished. Diderot creates a sort of chaotic fatalism with this passage, as indeed Jacques' tale will never be finished from within the narrative, but, each individual member of Diderot's audience will finish the tale for themselves. Diderot creates a truly chaotic text, something that begins as Diderot's novel and then instantaneously changes to the reader's once observed.

Diderot's text is perfectly in line with the central principles of the French enlightenment which were in opposition to absolutism, be it in monarchy, or dogmas of the church. Jacques indeed is a criticism of the absolute since it throws all sense of symmetry out of the window. To Diderot, symmetry is something observed and not absolute as his contemporaries believed. In Jacques, Diderot envisaged the places that his protagonists pass through as being outside of symmetrical linearity and even outside the physical confines of their places in the text. As in his Salons, Diderot considers the space surrounding the reader, his characters, and the text as dynamic spaces, crisscrossing each other from the moment the reader opens the book.

\section{Laurence Sterne: The Life and Opinions of Tristram Shandy, Gentleman}

Denis Diderot was hugely influenced by Laurence Sterne. The narrator in Jacques even blatantly states towards the end that second paragraph in the conclusion of the text «was copied out of The

${ }^{14}$ D. Diderot, Jacques the Fatalist and His Master, cit., p. 338. 
Life and Opinions of Tristram Shandy, Gentleman» ${ }^{15}$. Diderot then continues to playfully poke at Sterne with the next line «unless, that is, the conversations of Jacques the Fatalist and His Master pre-date that, in which case the Reverend Sterne is a plagiarist» ${ }^{16}$. Finally, Diderot pokes fun at recorded time, subjecting it to the readers' own knowledge of release dates, therefore making time a solid object instead of something abstract. Sterne's influence is also seen in the way that Tristram Shandy is very much a physical conversation with the reader, instead of a proper novel. Sterne manipulates dependency in his book to create a place where narrator, reader, and author occupy the same space.

By manipulating the manner in which the reader depends on the narrator, or not, Sterne creates his interactive «conversation» ${ }^{17}$. The reader can either follow Tristram's instructions or ignore them, either lengthening the average read time of the novel, keeping it the same, or shrinking it. Through the use of interactions with the reader, that serve as narrative interruptions and conflating texts, Sterne's proposed reading of Tristram Shandy becomes a sociable act which stands in direct defiance of Newton's clockwork universe. In the latter the clock ticks and ticks, life conforms to its linear progression, confined by its moving gears like text on a page. Unable to escape, humanity moves along, boxed in, progressing towards an ultimate end. Classical texts and conventional novels reflect this path: a reader picks one up, he or she reads it, making the gears on the page and the hands of the book advance towards its ultimate end. There is little resistance between reader and novel. Both are static, there is little interaction between the two. They are each separate in their own bubbles of existence. The reader follows the narrator mechanically, much like life follows the ticking hands of a clock. On the other hand, The Life and Opinions of Tristram Shandy, Gentleman, is one of the earliest examples of metafiction, of interactive text. Metafiction is a form of literature which places emphasis on the fixed nature of the narrative structure of the novel and where the narrator shows him or herself to be fully aware of his or her boxed nature. Furthermore, the narrator addresses his or her own awareness as well as the reader's, making the readers constantly aware that they are reading. In Shandy, reading

\footnotetext{
${ }^{15}$ Ibid, p. 252.

${ }^{16} \mathrm{Ibid}, \mathrm{p} .252$.

${ }^{17}$ L. Sterne, The Life and Opinions of Tristram Shandy, Gentleman, ed. by I. Campbell. Ross, Oxford University Press, Oxford 2009, p. 87.
} 
becomes a social act, more organic than mechanical. This challenges the idea of being trapped in a box with the endlessly swinging pendulum, fated to progress along with it. Narrator Tristram merges the separate bubbles between reader and novel. He destroys the concept of them both as static objects and creates a union between the two. Indeed, this was Sterne's object with Shandy as he had Tristram say, «writing, when properly managed ... is a different name for conversation ${ }^{18}$. There is a singular twist in Tristram's metafictional narrative, however. Tristram not only addresses the real reader, but a sort of invisible audience as well.

Tristram commands those he views as his audience to read chapter twenty, volume one over as he fears they have misunderstood what he was saying in chapter twenty, volume one, «how could you Madam, be so inattentive in reading the last chapter? I told you in it, That my mother was not a papist. - Papist! You told me no such thing, Sir. Madam, I beg leave to repeat it over again ${ }^{19}$. This cessation of the narrative causes a stop in time, leaving the characters where they were. This destroys the linear progression of the plot as Sterne's readers might also (or they might not) stop to look back over the chapter, in case something was missed. Another interesting thing that happens in this passage occurs only if the reader does go back. They find that they have not missed a single thing. There is no mention of Tristram's mother at all within the chapter. Tristram addresses this as well by stating he had said so by «direct inference» ${ }^{20}$. There is also an organic conservation within this text between reader and narrator. Tristram's addressed audience is an «audience ... [imagined] in the double sense that it corresponds to no actual body of readers and that it is, within the dramatic situation of the work itself, imagined by Tristram» ${ }^{21}$. Though indeed Tristram is alone while writing and his addresses do not actually correspond to a listening being in the room, they help solidify Sterne's imagined audience. By looping the reader in this address, the narrative time of the novel becomes further warped and chaotic. Ironically however, in making chaotic the narrative by this means of temporal control, Sterne (and Tristram) truly make writing an organic conversation. Tristram's imaginary audience becomes real in the form of Sterne's reader, and the process of writing becomes interactive. Thus, reading

\footnotetext{
${ }^{18}$ Ibid, p. 87.

${ }^{19}$ Ibid, p. 47.

${ }^{20}$ Ibid, p. 47.

${ }^{21}$ Dowling, W. C, Tristram Shandy's Phantom Audience in "Novel: A Forum on Fiction”, XII/3, 1980, pp. $284-295$.
} 
becomes not a mechanistic operation, but an organic one. Tristram interrupts the normal flow of clockwork time to make sure his audience, imagined or otherwise, fully understands the game he is playing.

Prior to this, there is an even more dramatic scene that gifts the reader control over the narrative time of the novel, highlighting its interactivity. Narrator Tristram invites his audience, if they are not curious at all about the events prior to his begetting to «- shut the door $»^{22}$. This is another ironic moment in the novel, where Tristram uses a mechanical act to induce an organic outcome. The door, very much like a pendulum, moves back and forth on hinges and both swing in the same motion. Unlike the pendulum, the door can close, thus stopping all movement, whereas the pendulum is constant and only stops if broken. In his article "Tristram Shandy, Bachelor Machine”, Roy C. Caldwell states that «Diderot's Encyclopedie (1750-1772) filled with diagrams of machines and descriptions of mechanical processes, testifies amply to the Enlightenment's fascination with new technologies, and its optimistic hope that machines would bring progress and prosperity» ${ }^{23}$. Though they did, for the most part, machines also brought terror, war and injury. Caldwell even states that Enlightenment aesthetics viewed the machine in a positive light, as an improvement over the «classical principle of imitation» Caldwell further states that it took until the end of the century for this view to change ${ }^{24}$. However, Tristram Shandy can be seen as an early attempt to dethrone the adoration for the machine that Enlightenment philosophers promoted. Caldwell also makes the point that the distrust of machines in Tristram's narrative is the dominant metaphor. This is indeed true as the entire novel is based around organic interaction versus mechanical.

In the scene cited above, «shut the door» is also a prime example of Sterne's tongue in cheek attitude $^{25}$. Instead of leading the reader along the narrative with him, Tristram gives the reader the opportunity to skip ahead in the plot, to jump forward, so to say, in time. Or he can refuse. Either way he is forced to make a choice and either choice disrupts the linear flow of the narrative. Similar to the creation of a time loop as seen above with the order to repeat the chapter,

\footnotetext{
${ }^{22}$ L. Sterne. The Life and Opinions of Tristram Shandy, Gentleman, cit., p. 8.

${ }^{23}$ Caldwell, R. C., Tristram Shandy', Bachelor Machine, in "The Eighteenth Century, XXXIV/2, 1993, pp. 103-114.

${ }^{24}$ Ibid p. 104.

${ }^{25}$ L. Sterne. The Life and Opinions of Tristram Shandy, Gentleman, cit., p. 8
} 
this forced choice creates an interactive, chaotic narrative. Ironically, this is done with the mechanism of a door: even the way the text is centered and «shut the door» is surrounded by long dashes looks like a door, signaling that the choice is the readers ${ }^{26}$. Tristram breaks the cage of the mechanistically static page and directly addresses his audience to contort the plot. He even pokes fun at his audience by saying, «I declare beforehand 'tis only wrote for the curious and inquisitive» ${ }^{27}$. In doing so, Tristram asserts himself, jumps outside the text to goad the reader into following him through the story of his begetting. This is a seemingly explicit attack on the mechanism of the door, a simple machine, but a machine nonetheless. The door opens to one path and closes behind it another. In Tristram Shandy, «shutting the door» allows the readers to close the door on the story of Tristram's beginning, admitting to the fact that they are not curious readers, and jump ahead ${ }^{28}$. Alternatively, they can close the door to the linear progression of the plot by following Tristram on this flashback. Giving the reader the ability to interact with the text's flow of time in such a way, produces the organic conversation of which Tristram boasts.

In one sense, the importance that Tristram places on the reader following his story, or shutting the door on it, validates Lucretius's statement that «time also exists not of itself, but from things themselves is derived the sense of what has been done in the past ${ }^{29}$. Sterne himself indicates the reader would best know Tristram through the «whole secret from first to last» ${ }^{30}$. Thus, even though Tristram is born outside of clock time (because of the interruption during his begetting), outside of the clock world, to get to understand him better, the reader must also be willing to venture back into the clock world. Upon venturing back into the clock world, the reader is able to get a better sense of Tristram through what influenced him. It then becomes clear that Tristram was strongly affected by the inability to communicate properly between the elder characters of the novel. This, for Tristram, translates into the inability to communicate anything at all properly and in an orderly fashion to the reader. Because of this method of interaction, a chaotic dichotomy is created from the linear progression of the novel. In her article "The Hobbyhorsical

\footnotetext{
${ }^{26}$ Ibid, p. 8.

${ }^{27}$ Ibid, p. 8 .

${ }^{28}$ Ibid, p. 8.

${ }^{29}$ T. L. Carus, De Rerum Natura, cit., p. 39.

${ }^{30}$ L. Sterne. The Life and Opinions of Tristram Shandy, Gentleman, cit., p. 7.
} 
World of Tristram Shandy", Joan Joffe Hall says «communication, frustrated by the hobbyhorse, repeats the tension between direction and interruption among characters» ${ }^{31}$. While communication between the characters of Walter, Toby and Trim is chaotic because of their disparate Hobby Horses, it can be deduced that these were ultimately what influenced Tristram. Walter Shandy loves to theorize, with very little concern for reality or the effects he has on others, such as his son Tristram claiming his father neglected him $^{32}$. Toby Shandy displays a kind of inverse Hobby Horse: a part of military science that was «fortification only» ${ }^{33}$. Tristram describes Corporal Trim, Toby's butler, as «the fellow loved to advise, - or rather hear himself talk» ${ }^{34}$. As stated earlier, it can be seen how these three separate Hobby Horses influenced Tristram. By jumping out of the page, a fortified space, he goes against Toby's love for fortifications. To counter Trim's love of hearing himself speak, Tristram makes his narrative chaotic by addressing the reader and jumping out of the text, warping the time in order to force the reader to follow him on his digressions. As for his father, Walter, Tristram's entire biography seems to be a response to his father's Tristapedia. While communication between characters is blocked, communication between narrator and reader is enhanced as the reader gets to know Tristram better. Writing becomes more conversational, as Sterne would suggest, because in order to fill in the blanks Tristram forces on his readers, the reader must get to know him well. Thus, a narrative of chaos is also born from Tristram's surroundings. Given the vast divide between the characters of Walter, Toby and Trim, the «conversation» Tristram so wished to create, would have necessarily been just as divisive. With interruptions at random spots, repetitions, and possibly incomplete conversations, it is no wonder that Tristram's own narrative is so chaotic.

This section began with a consideration of the audiobook effect on Tristram Shandy's narrative length. It then explored Tristram's games interacting with the reader and temporality. There is, however, another way in which narrator Tristram, author Tristram and author Sterne twist the fabric of the narrative in order to severely complicate the reader's job in progressing

\footnotetext{
${ }^{31}$ J. J. Hall, The Hobbyhorsical World of "Tristram Shandy", in "Modern Language Quarterly", XXIII/2, 1963, p. 131.

${ }_{32}^{32}$ L. Sterne. The Life and Opinions of Tristram Shandy, Gentleman, cit., pp. 300-301.

${ }^{33}$ Ibid, p. 74.

${ }^{34}$ Ibid, p. 77.
} 
through the novel: through making the reader fill in blanks, cut syllables and stare in awe at pages left blank, black as the void, or marbled. These narrative interruptions serve to give the reader nearly full control over the text. One of the most glaring instances of Sterne forcing the readers to think for themselves and fill in blank spaces.

\footnotetext{
Doctor Slop like a son of w-, as my father called him for it, - to exalt himself, — debased me to death, — and made ten thousand times more of Susanna's accident, than there was any grounds for; so that in a week's time, or less, it was in every body's mouth, That poor Master Shandy $* * * * * * * * * * * * * * * * * * * * * * * * * * * * * * * * * *$ entirely. - And Luck who loves to double everything, -in three days more had sworn positively she saw it, — and all the world, as usual, gave credit to her evidence

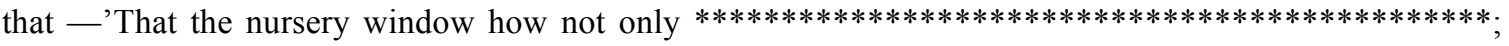
-but that $* * * * * * * * * * * * * * * * * * * * * * * * * * * * * * * * * * * * * *, \mathrm{~s}^{2} \mathrm{also}^{35}$.
}

These blanks in the text not only serve to make the reader work harder as he or she reads, they also massively distort Locke's notion of the association of ideas as well as Newton's notion of absolute time and space. While the audiobook would partially restore Newton's timescape, taking twenty-one hours to listen to the novel, describing the asterisks and ploughing through the narrative as if they were nothing, the individual reader would shatter it by taking their own time to fill out what is missing between the asterisks. This interaction between text and reader interrupts Tristram's train of ideas and allows the reader in, creating a space in which they can interact with each other and giving the reader as much power over the text as the author. Sterne works to make his readers interact with his narrator - Shandy - as well as with himself, the author. This transforms reading from an individual experience, to a social, conversational one. It is this idea of making writing into conversation that fuels Sterne's novel. For, in interrupting his own narrative with dashes and asterisks he «invite[s] the reader to complete the text himself $\rangle^{36}$. The reader's completion of the novel for him or herself is yet another element of chaos in the act of reading Tristram Shandy. It is

\footnotetext{
35 Ibid, p. 348.

${ }^{36}$ W. Iser, Tristram Shandy Laurence Sterne, translated by; David Henry Wilson, Cambridge University Press, 1988. p. 62 .
} 
these moments, where Tristram interrupts his narrative with asterisks and dashes, that truly create a new form of narrative time, an interactive time.

Instead of Tristram painting widow Wadman, the lady that uncle Toby falls in love with, for the reader, Tristram addresses the reader directly: «paint her to your own mind —as like your mistress as you can - as unlike your wife as your conscience will let you - 'tis all one to me - please put your own fancy in it» ${ }^{37}$. The rest of that page and the page that follows are completely blank, with only page numbers to mark the blank space. Allowing the reader to actually write or paint on the pages provided gives the reader control over the flow of the next page and a half of the novel. There is another set of blank pages in book nine, chapters eighteen and nineteen, which reinforces Tristram's desire to free the reader. These lacunae are not even addressed by Tristram until chapter twenty-five of the same book where he says, «all I wish is that it may be a lesson to the world, "to let people tell their own stories in their own way"» ${ }^{38}$. As do the asterisks and dashes, these blank pages severely cut into Locke's notion of the train of ideas and undermine Newton's clockwork hegemony. Even Lucretius's notion of time existing not «of itself» but as derived from the observation of changes the world of things holds no water here ${ }^{39}$.

Each and every reader has a past of his or her own, and can insert that into Shandy, telling yet another unique story as Tristram says he wants people to do. This serves to further the randomness of the text by creating multiple layers of plot within the larger framework. These various layers of possible narrative inside Tristram Shandy further scramble the duration of the text. The blank pages become the ultimate source of narrator-reader interactivity and create a variability of duration that further contorts the linearity of the novel. The reader can only fill in these blanks after he or she has come to know Tristram, as Iser says «it is the reader's task to draw conclusions, ... He must distrust his habitual expectations that ... it is his imagination that is to direct his comprehension, for only his imagination will enable him to follow the conservation of Tristram ${ }^{40}$.

\footnotetext{
${ }^{37}$ L. Sterne. The Life and Opinions of Tristram Shandy, Gentleman, cit., p. 376.

${ }^{38}$ Ibid, p. 524.

${ }^{39}$ T. L. Carus, De Rerum Natura, cit., p. 39.

${ }^{40}$ W. Iser, Tristram Shandy Laurence Sterne, cit., p. 63.
} 
Since the ultimate end of human linear progression is death, the chaotic structure of Sterne's Tristram Shandy embodies an allegory for the flight from death. Tristram's many instances of jumping outside of his caged page allude to this, since by being able to withdraw from the text's linear progression, he has hopes of removing himself from the life/death continuum. While Tristram himself survived a near scrape with death, Sterne the author, was surrounded by those ill or dying and he himself, was dying from tuberculosis. Tristram's (and Sterne's) fear of death is cemented in black by the pages directly after Yorick's death, where he uses so much ink that not only does it blot one page, but it seeps through to the next. The interruption of the black page right after this death «expresses the incomprehension arising from the absolute incommensurability of death» ${ }^{41}$. In book seven of Tristram Shandy, this is underlined by Tristram's trip to Europe for his health. «When Death himself knocked at my door - ye (Tristram's spirits) bad him come again; and in so gay a tone of careless indifference did ye do it [...] as that son of a whore has found my lodgings» ${ }^{42}$. It makes sense, then, that beginning with this encounter with death the novel becomes even more chaotic, with more interruptive dashes, asterisks, and more blank pages, with the intention of splitting the linear progression of his life off onto another track.

Still the clock ticks and with it life progresses as does the novel to its ultimate end. Tristram, being the hyper-sensitive narrator that he is, is very much aware of this. After his scrape with death in the scene above, he states that «I have forty volumes to write, and forty thousand things to say and do, which no body in the world will say and do for me» ${ }^{43}$. Not only is Tristram's telling of his life an answer to his father's Tristrapedia but it is also a response, and an opposition to his own impending death. As mentioned earlier, death is the only outside force that can control the fabric of the novel. Tristram is attempting to flee from this force by weaving the progression of the plotline through various interruptions and digressions. Thus, while the black page may be one of Tristram's ways of attempting to comprehend the incomprehensibility of death, the marbled page expresses the «chaos of

\footnotetext{
${ }^{41}$ E. Zimmerman, Tristram Shandy and Narrative Representation, in "The Eighteenth Century", XXVIII/2, 1987, pp. 127-147.

${ }_{42}^{4}$ L. Sterne. The Life and Opinions of Tristram Shandy, Gentleman, cit., p. 385.

${ }^{43}$ Ibid p. 386.
} 
narrative and of the book» ${ }^{44}$. Tristram calls upon his reader to «read, read, read, read, my unlearned reader! Read!» ${ }^{45}$. In calling such attention to the act of reading, Sterne forces his reader to not just read the text but, to complete it as well. This forces the reader to become part of the text as much as the author, storyteller and implied storyteller are. By doing this, Sterne makes the imaginative reader a co-narrator of the story. The reader is placed in a state that is both simultaneously reader and author. The interruptions in the text force Tristram Shandy's readers to actually think while they read the text, underlining the notion that time and space are not absolute. The fact that there is no set duration nor dimension to progress through the narrative and no easy way to do so, gives Tristram a means to dodge his ultimate fate.

Infamously, Doctor Samuel Johnson stated of Sterne's Tristram Shandy that «nothing odd will do long. Tristram Shandy will not last» ${ }^{46}$. Tristram Shandy, however, did last. It is because of the oddity that Johnson berated that it has lasted. This oddness that Johnson comments upon is further encouraged by Sterne's assertion that he writes what he found «laugh-at-able» ${ }^{47}$. The novel is indeed one huge farce from its title to its core elements. The varying length of its chapters parodies the popular concepts of time in the eighteenth century. The erratic chapters signify that the mind is not orderly, as philosopher John Locke would posit, with his constant and regular train of ideas. Rather, the mind jumps from one notion to the next, at varying speeds suggesting the notion that disorder is what governs the person. Shandy represents a person that is completely erratic and irrational, jumping from one point to the next, leaving the reader in suspense, defying the known laws of physics. Sterne works to show that portraying his persona as incoherent is truer to reality than painting a coherent character.

\footnotetext{
${ }^{44}$ E. Zimmerman, Tristram Shandy and Narrative Representation, cit., pp. 127-147.

${ }^{45}$ L. Sterne. The Life and Opinions of Tristram Shandy, Gentleman, cit., p. 180.

${ }^{46}$ J. Boswell, Life of Johnson. Dent, 1962, p. 696.

${ }^{47}$ L. Sterne. The Life and Opinions of Tristram Shandy, Gentleman, cit., P.180. p. 74.
} 
The term Shandy as Sterne coined it, has held its meaning over time. The definition from the Concise Oxford Companion to English Literature is «crack-brained and half-crazy» ${ }^{48}$. It is the crack-brained and half-crazy nature of Sterne's novel that makes it impossible to subdue it to any sort of structural order. Whenever literary critics attempt to show that Shandy holds some semblance of order, they come up short by failing to realize the complexity of the work. Its chaotic structure represents Sterne's «point of ridicule» at the orderly world conceived by both scientists and philosophers of his day ${ }^{49}$. This is the root source of farce in Tristram Shandy. The notion that time can be manipulated, as Tristram does, is what creates the narrative's fantastic interactive nature. Therefore, to the individual, the passage of time is never «constant and regular» as Locke would have $\mathrm{it}^{50}$. By rejecting Locke's notion of time, Sterne rejects Newton's notion of the clockwork universe. Sterne does use Lucretius' concept of time for Shandy's conception at the beginning of the novel to start the story of his life. However, this is the only point of Lucretius' that Shandy follows as the narrator then places himself separate from linear time. From that moment onwards, Tristram definitely displays a sense of time that is outside of its movement.

Tristram Shandy is a novel that is infinite in its well of interpretation. Twenty years ago, Clark Lawlor stated, «one would think that the subject of time and Sterne, especially in Tristram Shandy, had been entirely exhausted» ${ }^{51}$. Yet the rise of chaos theory in regard to Sterne's novel breathed new life into the study of time and narrative. The lens of chaos allows for a more minute study of the interactivity of Sterne's novel and Tristram's games with time. The study of interactivity in Sterne's text draws attention to the conversational nature of Sterne's writing. Iser appropriates this conversational style of writing when he states that a text remains static until it is acted upon, that when a reader comes to a text, he or she places their own meaning on it. Thus, like a hydra regenerating its many heads, readers

\footnotetext{
${ }^{48}$ M. Drabble. J. Stringer, The Concise Oxford Companion to English Literature, Oxford University Press, Oxford 1996, p. 647.

${ }^{49}$ L. Sterne. The Life and Opinions of Tristram Shandy, Gentleman, cit., p. 74.

${ }^{50}$ J.-C. Sallé. A Source of Sterne's Conception of Time, in "The Review of English Studies", VI/22, 1955, pp. 180182.

${ }^{51}$ C. Lawlor, Consuming Time: Narrative and Disease in "Tristram Shandy" "The Yearbook of English Studies", XXX, 2000, pp. 46-59, p. 147.
} 
regenerate areas of study literary critics once thought exhausted. Iser is one of the few critics who engages with Sterne's interactivity, stating that the blank spaces, asterisks, left out words, dashes, black pages and every other interrupter in Tristram Shandy serve to keep readers on their toes, to keep them guessing and working for themselves to complete the text. Keeping the readers on their toes essentially forces them to engage more with the text, to not just passively read from start to finish. Taken from his father, though not completely, Tristram does not have proper animal spirits guiding him throughout his life. Because of this, he is able to jump outside of the text, and interact with his audience. The interactivity of the novel is one of its most important aspects. Without it, Tristram would not be able to manipulate time from within the way he does.

\section{Conclusion}

Sterne and Diderot's distortion of time within their novels is of vast importance as it shows how other genres have borrowed from them. Commonly hailed as predecessors of modernist and postmodernist work, Shandy and Jacques develop this interactive style of narration more than a century before its time. In the case of Sterne's Tristram Shandy, the narrator becomes an active agent, giving Tristram a form of artificial life when he lets the reader into the text to fill in all of his blanks. Contrarily, when Tristram does not take control of his narrative, allowing it to flow sequentially, he reverts to the regular, passive narrator. Comparatively, in Diderot's Jacques, the narrator acts as both active and passive agent in the same instance. The novel is constructed as a conversation, therefore allowing the narrator to jump in and out with the reader at any point. This creates a chaotic form of metalepsis, where the narrator is both narrator and narratee when the reader is pulled into the story and ordered the reader to complete the text however they please. Both Tristram Shandy and Jacques the Fatalist represent «the chaotic text par excellence» as both narrators become like Schrodinger's cat, creating a Schrodinger's narrative where the novel is both finished and unfinished ${ }^{52}$. The chaotic element in these novels aligns them with a very

\footnotetext{
52 J. A. Parker, Narrative Form and Chaos Theory in Sterne, Proust, Woolf, and Faulkner, Palgrave Macmillan,
} 2007, London, p. 32. 
modern concept in physics. It serves to further the connection and mutual influence between literature and science. Though Diderot and Sterne might never have known or been able to predict such a concept as scientific chaos, Jacques and Tristram Shandy's chaotic landscapes definitely gave scientists a different blueprint with which to navigate 